\title{
Religious freedom and Riddah through the Maqāṣidī interpretation of Ibn 'Āshūr
}

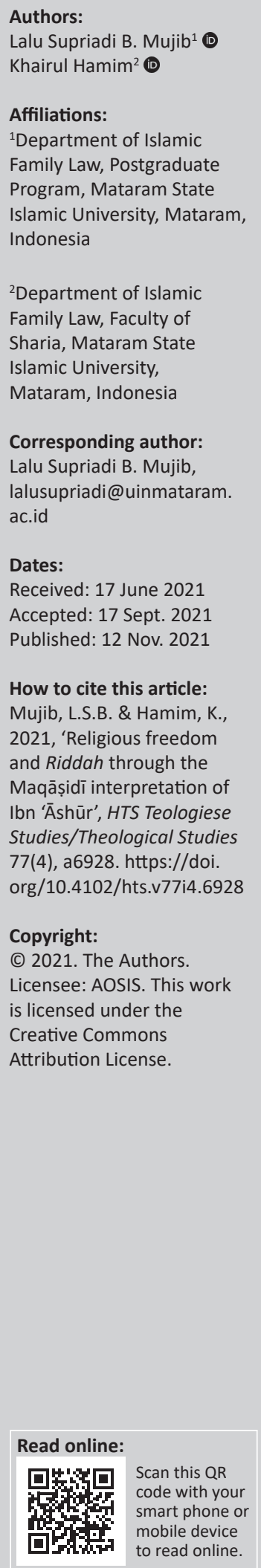

The concept of riddah (apostasy) in Islam is a controversial issue, especially when it comes to religious freedom. Therefore, this article aims to analyse the application of the Maqāșidi (Higher Objectives of Islamic Law) interpretation of Ibn 'Āshūr in interpreting the verse on religious freedom in relation to riddah. According to Ibn 'Āshūr, the main objectives in revealing the Qur'an are based on three things, namely șalāh al-ahwwāl al-fardiyyah (individual betterment), șalāh al-ahwwāl al-jamā'iyyah (collective good) and șalāh al-aḩwāl al-'Umrāniyyah (the good of civilisation). Salāh al-ahwwāl al-fardiyyah provides meaning to the fulfilment of individual rights, such as the freedom of choice in belief or religion. Thus, in Ibn 'Āshūr's view, religion, which is considered something personal, is used to determine communal good and inevitably influences the goodness of human civilisation in the world. Based on the Maqāṣidi Interpretation of Ibn 'Āshūr, this article argues that the death penalty for riddah needs to be reinterpreted for theological, historical and political reasons. Furthermore, its imposition is contrary to the dimension of hifz al-nafs (guarding the soul) and hifz al-din (maintaining religion).

Contribution: This article provides insight into the contribution of Ibn 'Āshūr through the Maqāsidi interpretation in viewing the issue of religious freedom in relation to riddah. It contributes theoretically to become a conceptual framework to respond to the issue of riddah.

Keywords: religious freedom; riddah; Maqāșidī interpretation; Maqāșid Sharī'a; human rights.

\section{Introduction}

Muhammad al-Ṭāhir Ibn 'Āshūr (1879-1973 AD) was an extraordinaryly contemporary Tunisian Muslim thinker who contributed profoundly to the development of Islamic thought in the 20th century. His monumental work known as Maquașid al-Sharī'a al-Islāmiyya (The higher objectives of Islamic law) educated Muslim jurists on the importance of the maqāṣid sharī'a approach in understanding Islamic law. He included several contemporary themes, which maqāșid alsharī'a addresses, such as the nature of humankind (fitra), tolerance (samāha), benefit (mașlaha), equality (musāwā) and freedom (hurriyya) (Ibn 'Āshūr 2011). Furthermore, he critiqued the discipline of usul al-figh (principles of jurisprudence), which is the methodology used to extract legal rulings from the primary texts of Islam, by establishing Maqāṣid al-sharī'a as an independent science.

Maqāșid al-sharī'a was demonstrated to be broader than usul al-figh. Usul al-figh in Ibn 'Āshūr's view only led to debates on matters associated with fur $\bar{u}^{\prime}$ (outcomes) and not the broader context or universality of Islamic law (Ibn 'Āshūr 2011). Moreover, usul al-figh emphasises the linguistic aspects which are laden with literal textual understanding and ignores Islamic law's core purpose and comprehensive substance (maqāșid sharī'a). Ibn 'Āshūr's views are echoed in the works of contemporary scholars such as Auda (2008) and Arkoun (1988). Thus, Ibn 'Āshūr opines that usul al-figh is a theory of the formulation of Islamic law, while the knowledge of Maqāṣid al-Sharī'a acts as its philosophical foundation.

Ibn 'Āshūr's Maqāṣid al-Sharī'a paradigm tremendously influences his style of thought as outlined in his exegesis (Tafsir) of the Quran, al-Tahrīr wa al-Tanwīr, a work produced prior to Maqāșid al-Sharī'a al-Islāmiyya. Based on Ibn 'Āshūr's legacy, contemporary scholars have adopted the maqāșidī interpretation style (Kusmana 2015), which seeks to interpret the Qur'an in a transformative contextual manner (Fikriyati 2019). From the above-mentioned works and its impact on the Muslim world, Ibn 'Āshūr has demonstrated his position as an expert commentator on Islamic law. Moreover, his thoughts and interpretive style were applied to the issues faced by the society at that time culminating in the work of Ușūl al-Nizấm al-Ijtima $\bar{a}^{\prime} \bar{l}$ fi 
al-Islām. Hence, Ibn 'Āshūr has taken his place amongst the reformists in the field of Islamic law and social interpretation of the 20th century.

The maqāṣidī interpretation of Ibn 'Āshūr on religious freedom in relation to apostasy (riddah) has put forth the need for the revaluation and interpretation of the death penalty for those who commit apostasy, which in the Islamic context are those who leave the religion of Islam (Baker 2018). A case can be made that the death penalty that was imposed on riddah perpetrators during the Prophet's (peace and blessings be upon him - PBBUH) time was not because of apostasy per se, but rather it was a result of undermining Islam and the Islamic community as well as it being an open act of rebellion (Mohamed Adil 2007; Sumbulah \& Purnomo 2017). The application of the death penalty in the contemporary context, thus, contradicts all arguments textually and contextually, especially the enforcement of human rights (Saeed \& Saeed 2004).

\section{Literature review}

Preliminary studies have put forth several theories, methods and approaches used to examine the relationship between religious freedom and riddah. For instance, Abdul Karim Soroush's contraction and expansion theory of religious knowledge showed that the death penalty for apostasy in the early days of Islam was interpreted and implemented according to the socio-historical context (Akbar 2018). Furthermore, the analysis of the social history of the hadiths (prophetic traditions) showed that the death penalty for riddah was motivated by war and social crimes (Assagaf 2014). Moreover, Abdullah Saeed's progressive Islamic deductive method shows that the death penalty for riddah does not have a clear-cut, strong argument in the Qur'an and Hadith texts (Musif 2015). Akbar (2018) and Saed (2006) thus argued that contemporary Muslim thinkers, in both Sunnī and $S^{-1}{ }^{\prime} \mathbf{1}$ sects, agree that riddah is a personal, individual matter, and therefore should not lead to the imposition of death penalty (Akbar \& Saeed 2020).

Several studies have examined the use of the maqạsidi interpretation theory at theoretical as well as applicatory levels in several aspects of life. Maqāșidī interpretation theory has been applied in interpreting the Qura'nic verses concerning war in the Indonesian context (Fikriyati 2015), as relating to freedom by Ṭāha Jābir al-'Alwānī (Fawaid 2017), versus in the realm of democracy (Nikmah 2017) and regarding tolerance among believers of various religions in Indonesia (Hasan \& Kholiq 2018). Furthermore, several studies present various theories and approaches in accordance with the research carried out by Ibn 'Āshūr, such as Malasevic's theory of political identity (Herlambang \& Juliandi 2018). Herlambang and Juliandi using this approach found that Ibn 'Āshūr's interpretation of thought was influenced by Islamic identity politics, which failed to recognise the role of non-Muslims. This is evident in Ibn 'Āshūr's negation of non-Muslim's involvement in the consolidation and national development of Tunisia.
Another view purported that Ibn 'Āshūr had an ambiguous attitude towards religious and political relations. This was demonstrated in Ibn 'Āshūr's broader stance in providing space for religious freedom for non-Muslims, while narrowing and negating the political role of non-Muslims (Nuruddin et al. 2019).

The interpretation of the Qura'nic verses regarding religious freedom in a transformative contextual manner presents a solution to various crises that have disrupted relations amongst believers of various religions in Indonesia in particular and multireligious societies in general. This research thus aims to complement and bridge the gap that exists in previous studies by analysing the concept of the maqāṣidī interpretation of Ibn 'Āshūr in terms of religious freedom with a particular relation to the riddah.

This study argues that Ibn 'Āshūr's concept of religious freedom in relation to riddah needs to be studied more to propose a conceptual framework for responding to contemporary global issues relating to equality, benefit, freedom and the enforcement of human rights. Furthermore, Ibn 'Âshür's thought is often misapplied and used to refute 'erroneous' views regarding people's perceptions toward different religions, which leads to the disruption of relations amongst multireligious communities. This erroneous usage often arises because of a misunderstanding in the interpretation of the verses of the Qur'an. One of the contributing factors is ignoring the maqāssid or goals behind the Qur'an. According to Auda (2008:27), the tendency for someone to understand the verses of the Qur'an is influenced by the hegemony that dominates the understanding of verses. Generally, one side understands it textually (scriptural), and the other contextually (liberal). Between these two tendencies, the maqāsid interpretation is the interpretation of moderation (the middle way), which understands the verses of the Qur'an, and the necessity in combining the text and context (Auda 2008).

\section{Religious freedom}

Respecting religious freedom is a principle used to build harmonious relations amongst multireligious communities. This principle is not only a Muslim human need, but rather a universal value accepted by all religions. In the contemporary era, the obligation to respect human freedom is intertwined with upholding human rights. Discriminatory attitudes go against the spirit of protecting human rights. Therefore, knowledge of the social dynamics of religious life is necessary to understand religious texts intricately and contextually (Noorhidayati 2016). Allah gives freedom to all people to choose their religion, therefore, because of this value of freedom (freedom of choice and freedom of religion), it is not permissible to impose religious coercion on others. However, Allah also takes to reckoning in the hereafter those who did not accept and adhere to His revealed religion. Therefore, freedom of religion is an individual religious affair between humankind and God. 


\section{Riddah}

Riddah in Islamic law is to change one's religious belief from Islam to other faiths. This term has continuously evolved in meaning and implications across the ages. In the Meccan phase, the basic meaning of religious freedom was an individual affair between Allah and humans. The new meaning of riddah as an act wherein the death penalty is imposed for the one who commits it, manifests only in the Medinan phase. At the time of khulafā al-rāshidīn (rightly guided successors of Muhammed PBBUH), the meaning, implications and consequences of riddah were strengthened because of the superiority of Islam as a political force. Furthermore, during the Umayyad period and the beginning of the Abbasid period, the meaning of political honour was tied to Islamic superiority. It was during this period that nonMuslims were punished for committing riddah (Saed 2006).

\section{The Maqāṣidī interpretation}

Maqāṣidi Interpretation is not a new discourse in Islamic scientific discourse; but has been introduced previously by classical and contemporary Muslim thinkers. Tāzul Islam identifies the contributions of classical Muslim thinkers in this field such as Abū Hāmid al-Ghazālī's (died in 1111 AD) Jawāhir al-Qur'ān, 'Iz al-Dīn b. 'Abd al-Salām's (died in 1261 AD) Qawā'id al-Aḥkām Fō Maṣālih al-Anām, Ibrāhim al-Biqā̄'î́s (died in 885 H) Nažm al-Dhurar fī Tanāsub al-Āyāt wa al-Suwar and al-Shațibī's (died in 1388 AD) al-Muwāfaqāt fì Ușūl al-Shari'ah. If the previous classics were limited to partial mention of Maqāṣidī Interpretation, a more comprehensive discussion was carried out by several contemporary Muslim thinkers such as Rashīd Riḍā's (died in 1935 AD) Tafșìr al-Manār, Abū al-A'lā al-Mawdūdī's (died in 1989 AD) Tafhīm al-Qur'ān, Sayyid al-Quṭb's (died in 1966 AD) Fī Zilāl al-Qur'ān, Ibn 'Āshūr's (died in 1973 AD) al-Taḥrīr wa al-Tanwīr, 'Izzat Darwazah's (died 1987 AD) Tafșìr al-Hadìth and Yūsuf al-Qarḍāwī's (born in 1926 AD) Kaifā Nata'āmal $M a^{\prime} a$ al-Qur'ān. In subsequent developments, a theoretical discourse emerged on the concept of Maqāṣidi Interpretation more specifically by Ḥannān Lahhām in his work of Maqāṣidi al-Qur'ān al-Karìm Min Tashrī' al-Ahkām (2004) and 'Abd al-Karīm Ḥāmid̄̄ in his work of al-Madkhal Ilā Maqāṣidi al-Qur'ān (2007) (Islam 2011, 2013a, 2013b).

Maqāṣidī Interpretation is currently a trend in the interpretation of the Qur'an because it is considered a very relevant method in responding to various present-day challenges and problems. Ibn 'Āshūr using this method is believed to be able to build Islamic legitimacy for moral, legal and political commitments (March 2011). This trend is evidenced by the emergence of various works that either directly uses the terminology of the Maqāșidi Interpretation or the terminology of maqāssid al-Qur'an. The purpose of establishing Islamic law as emphasised by Abū Ḥāmid Al-Ghazālī is to realise the maintenance of five religious principles (al-Darūriyāt alKhams), namely, preserving religion (Hifz al-Dinn), preserving the soul (Hifz al-Nafs), preserving mind (Hifz al-'Aql), maintaining property (Hifz al-Māl), and maintaining offspring
(Hifz al-Nasl) (Abu Hamid al-Gazali n.d.). Therefore, by changing the order of priority to these five principles, as stated earlier, al-Shâtibī emphasised that the purpose of establishing Islamic law is to preserve religion, preserve the soul, preserve mind, maintain offspring and preserve property (Al-Shāțibī n.d. 2:8-9).

Maqāṣidī Interpretation is a model approach to the interpretation of the Qur'an, which emphasises the dimensions to realise the benefit and reject damage based on the fundamental of Qur'anic values, namely al-'adāla (justice), al-musāwo (equality), al-insāniyya (humanity) and al-wasațiyya (moderation) (Mustaqim 2019).

The Maqāșidi Interpretation method inherently emphasises all aspects of life which exist in the Qur'an, including theology, law, mu'ámala (transactions), stories and amtsāl. Thus, Imam Al-Ghazali proposed that the purpose of establishing Islamic law or any universal law is to realise the protection of five religious principles (al-Darūriyāt al-Khams), namely maintaining religion (Hifz al-Dinn), preserving the soul (Hifz al-Nafs), mind (Hifz al-'Aql), descendants (Hifz al-Nasl) and property (Hifz al-Māl) (Abu Hamid al-Gazali).

In the perspective of al-Shathibi, the concept of maintaining primary objectives (hifz maqasid al-Darüriyāt al-Khams) is divided into two. The first confirms the realisation of the primary goal (Jānib al-Wujūd), while the second prevents its obstruction (Jānib al-'Adam). Some examples of hifz al-dīn (maintaining religion) and Jānib al-Wujūd include believing, praying, fasting and other forms of worship. According to the majority of classical Maqasidi scholars, hifz al-din (guarding religion) needs to take precedence over hifz al-nafs (guarding the soul). Based on this opinion, the perpetrator of riddah needs to be put to death as part of hifz al-din min jānib al-'adam (something that prevents the primary goal from being prevented), rather than being allowed to live safely as part of hifz al-din min janib al-wujud (something that confirms the realisation of the primary goal) (Al-Shātibīn.d.).

However, the response of a contemporary Maqasidi scholar, Jaser Auda is that hifz al-nafs (guarding the soul) needs to take precedence over hifz al-dinn (protecting religion). In this case, when someone commits apostasy, the perpetrator must be allowed to live safely. Furthermore, when someone commits apostasy causing rebellion and war against the legitimate government, constitution and law of the country, the punishment is death. This indicates that life takes precedence over religion because one of the parts of hifz al-nafs min jānib al-'adam prohibits rebellion and determines punishment for the act (Auda 2008).

\section{Research methods}

This is qualitative research with primary and secondary data obtained from a library using documentation from printed and electronic books and journals. The obtained data were analysed in three stages in accordance with Harold D. Lasswell research. The first stage describes the 
contents of the message in the form of the characters' thought being studied. The second examines the causes of the message content on behaviour which is capable of raising values, attitudes, motives and problems at the source of the message. The third analyses the impact or implication of message content on the recipient (Koentjaraningrat 1990).

\section{Result}

Methodologically, the position of Maqāṣidī Interpretation is aligned with several previously known interpretation methods, namely tahlīlī, ijmāli, muqāran and mawdị $\bar{u}^{\prime} \hat{\imath}$ (Umayah 2016). The method of Maqāșidī Interpretation differs from other methods because its interpretation of the Qur'an emphasises the maqāșid dimensions of the Qur'an in order to realise the benefit and reject damage, based on the fundamental of Qur'anic values, namely al-'adālah (justice), al-musāwāh (equality), al-insāniyyah (humanity) and al-wasatiyyah (moderation) (Mustaqim 2019). It is supposed that it is related to the material object of the Qur'an concerning legal verses. In that case, Ibn 'Āshūr's interpretation of Maqāșidī was theoretically and conceptually developed from the five principles of Maqāsid Sharīa put forward by several experts in Islamic law and jurisprudence such as al-Ghazālī and al-Shātịīi. It, especially, is concerned with the maintenance of the dimensions of Hifz al-Din (preservation of religion).

However, in practical terms, Ibn 'Āshūr develops the operational scope into contemporary and contextual issues (Ibn 'Āshūr 2011). It is done so that Islamic law can respond to various challenges of the times. While it is elaborated with contemporary maqāṣid̄ thinking, the scope of Maqāṣid Sharia that Ibn 'Āshūr has worked on has a close relationship with the thoughts of contemporary maquasidi $\bar{\imath}$ (Islamic legal theory) experts such as 'Allāl al-Fāsī and Yūsuf al-Qarḍ̂̄wī. Al-Qarḍāwī developed the scope of Maqāṣid 'Āmmah (public interest), which Ibn 'Āshūr initiated into several new scopes, including social, economic and political relations. Yasir S. Ibrahim considered that al-Qarḍāwī succeeded in emphasising respect for human rights in Islamic law and religious mandates to achieve economic and political justice by implementing a democratic system of government (Ibrahim 2014). Likewise, al-Fāsī includes human rights such as the right to life, honour and the right to freedom as part of the goals of Islamic law. This right to freedom concerns physical freedom (physical) and includes non-physical freedoms including religion and belief (al-Fāsī 'Allāl 1995). We argue that this happened because of the socio-historical context behind the life and thoughts of Ibn 'Āshūr and al-Fāsī. It was marked by a change in the global order system of the Islamic world from a state of an Islamic state (dawlah Islāmiyyah) and after the collapse of Dawlah Osmāniyyah in which it turned into a nation-state. In the nation's order-state, global issues such as equality of rights, benefit, freedom and the enforcement of human rights are universal values that must be upheld.

\section{Ibn 'Āshūr's fundamental thought in Maqāșidī interpretation}

Ibn 'Āshūr employed the Maqāșidī Interpretation in his Qur'ânic exegesis. Țahā Jābir al-'Alwānī stated that the Maqāṣidī Interpretation of Ibn 'Āshūr is a form of integration of two considerations between revelation (text) and context or reality $\left(w \bar{a} q i^{\prime}\right)$. Therefore, ignoring one of them causes the interpreter to fail to reach perfection in understanding the Qur'an (Al-'Alwânî 2014). According to 'Alwānī, when people go beyond the first recitation and only focus on the second reading, they lose connection with Allah. On the other hand, when people rely on the second reading, they run away from the world and destroy human potential in building civilisation, which is contrary to the manhaj (method) of the Qur'an (Al-'Alwânî 2014).

Ibn 'Āshūr stated that the Qur'an was revealed to enhance human affairs (li salāh amr al-nās käffah). It is a form of grace for the universe to assist humans in achieving the goals desired by Allah. Three main axes need to be fulfilled to realise this goal, namely as mentioned before, șalāh al-ahwwāl al-fardiyya (individual betterment), șalāh al-aḩwāl al-jamā'iyya (collective good), and șalāh al-ahwwāl al-Umrāniyya (the good civilisation). Individual improvement is based on purifying the soul by improving faith (belief), which is the source of all ethical forms and mindsets that lead to the increase in good. This is implemented specifically in the form of physical worship such as praying, fasting, zakat (giving alms) and spirituality. It is also associated with proper ethics, such as abandoning the feeling of envy, arrogance and so forth.

Collective goodness emerges from individual betterment because they are the building blocks of collective society. It, therefore, holds the assumption that the individuals who form the collective are good. This comprises the process of forming a system of order that regulates the behaviour and actions of people to curtail them from following their animalistic or lower desires. This system of control and social order implemented by Ibn 'Āshūr is called al-siyāsa almadāniyya (civil politics). The goodness of civilisation acts as a system that governs numerous communities and groups living in various parts of the world (countries) and in the Islamic world. Apart from that, it is a system to realise common interests and universal benefits when there is a conflict between the general good and the specific individual benefit (Ibn 'Āshūr).

\section{Ibn 'Āshūr's interpretation of the verse on religious freedom}

In the Qur'an, there is a verse that instructs Muslims to uphold the principle of religious freedom, which is reflected in the prohibition of Muslims from practising religious coercion. Allah said:

$[T]$ here shall be no compulsion in [acceptance of] the religion. The right course has become distinct from the wrong. So, whoever disbelieves in țaghhūt and believes in Allah has grasped the most trustworthy handhold with no break in it. And Allah is Hearing and Knowing. (the Qur'an, Al-Baqarah, 2:256) 
This means that it is not compulsory to be a Muslim. However, it is better to choose the right path rather than the wrong one. Therefore, whoever denies al-tâg $\bar{u} t$ (false deities or falsehood) and believes in Allah needs to hold onto a very strong rope that is not broken. This is because Allah is All-Hearing and All-Knowing (the Qur'an, AlBaqarah 2:256).

Some opinions reveal the socio-historical context of the reason for the revelation of this verse ( $a s b \bar{a} b$ al-nuzūl). The most significant reasons, according to al-Țabarī are two things. Firstly, the verse was revealed for some Ansar (medina residents) people with children that embraced Judaism and Christianity. When Islam was introduced, their parents wanted to force their children to convert, however, they refused. Secondly, this verse was revealed to one of the Ansars named Sālim b. 'Awf also known as al-Husayn with two sons. Traders from Syria who were non-Muslims came to Makkah to carry out business. When they wanted to return to Syria, the merchant invited two of the al-Husayn's sons to embrace Christianity, and both became Christians and went to Syria. However, their father was angry and wanted to force them to convert back to Islam, and they both refused (al-Ṭabarī 2001).

There are at least two main interpretations among commentators (Qur'an, Al-Baqarah 2:256). Firstly, the verse uses informative sentences (kalām khabarī), with a performative meaning $\left(\right.$ insh $\left.^{\prime} \bar{\imath}\right)$, which contains a command not to carry out religious coercion because there is the letter of $l \bar{a}$ náfiah (lā which means no or negation). Furthermore, this verse emphasises that matters of faith do not need to be carried out by force because compulsion in religion leads to hatred. Authentic diversity comes from sincerity, therefore, al-Zamakhsharī (1407) stated that religious desire needs to emerge from the heart based on choice and a voluntary attitude. Secondly, the redaction of the verse is in the form of nafyu (negation), although the meaning is nahyu (prohibition). This means that Allah forbids Muslims to enforce religious coercion against nonMuslims by fighting them.

Ibn 'Āshūr agrees with the second opinion by saying that (the Qur'an, Al-Baqarah 2:256) it does not apply the law in verses that contain orders to fight against nonMuslims. According to Ibn 'Āshūr, the event of Fathu Mecca (conquering the city of Mecca) became a historical phase where religious coercion was no longer allowed because of the increasing number of Muslims resulting in political strength and dominance.

Some of the arguments put forward by Ibn 'Āshūr include the opinion of Ibn 'Abbās, as highlighted by al-Ṭabarī, who stated that the verse was revealed after the number of Muslims increased, followed by the laws for the People of the Book (Jews and Christians) and followers of the Magūs religion to pay jizya (taxes). In addition, this verse was revealed after Fathu Mecca (the conquest of the city of Mecca). Ibn 'Āshūr (n.d.) stated the following:

[F]athu Mecca was marked by several events, such as the disappearance of all forms of practices linked to shirk in the Ka'bah and Mecca. Many people voluntarily converted to Islam, and some envoys (ambassadors) from friendly countries (Arabs) came to Mecca... When this happened, Allah eliminated warfare in the name of religious coercion (the Qur'an, At-Tawbah 9:29). With this, the verse $l \bar{a}$ ikrāha fĩ al-dīn nullifies the one, which contains the command to fight against non-Muslims. (the Qur'an, At-Tahrīm 66:9)

However, this is different from al-Tabarī's view, which stated that this verse has a special meaning and designation, which applies to the ahl al-kitāb (Jews and Christians) and the followers of the Magūs religion that paid jizya as a form of their recognition of Islamic rule at that time (al-Țabarī 2001). This is also different from Ibn Taymiyyah (n.d.) who stated that the verse generally means that it is not permissible for someone to enforce religion and fight against non-Muslims. Ibn Taymiyyah interpreted (the Qur'an, Al-Baqarah 2:256) it as no one is forcefully converted to Islam, rather we fight against enemies. The property and blood of those that convert to Islam are preserved.

This is also contrary to the opinion of Ibn Kathīr who emphasised that this verse was abrogated (the Qur'an, AtTawbah 9:73) (Al-Qurtubî 2002). By quoting the opinions of Ibn Mas'ud, Ibn Zayd and Sulaymān bin Mūsā, Ibn Kathīr emphasised that (Qur'an, Al-Baqarah 2:256) it is not applied in isolation, rather it must be linked to other verses that expound it, namely 'O Prophet! Struggle against the disbelievers and the hypocrites and be firm with them. Hell will be their home. What an evil destination!' (the Qur'an, At-Tahrīm, 66:9). According to Ibn Kathīr, all humans need to be called to Islam and when they object, without paying jizya, they need to be fought (Kathîr 1999). Another reason put forward for saying that (Qur'an, Al-Baqarah 2:256) is limited in application to religious freedom was because of the fact that some scholars quantitatively calculated fewer verses supporting religious freedom. Therefore, according to Ibn Kathīr, the hundreds of verses ordering the execution of polytheists and disbelievers cannot be automatically cancelled by a handful of those that wish to leave the polytheists with their polytheism and the disbelievers.

Muslims argue that the opinion stating that (Qur'an, AlBaqarah 2:256) which has been abrogated by āyāt al-Qitāl, 'O Prophet! Struggle against the disbelievers and the hypocrites and be firm with them. Hell will be their home. What an evil destination!' (Qur'an, At-Tawbah 9:73) has no solid foundation for several reasons. For instance, the verse in at-Tawbah, which contains the incident of 'breaking the promise' of non-Muslims in the Hudaybiyya agreement and the 'order to fight against non-Muslims', does not mention religious coercion.

$[A]$ nd if anyone from the polytheists asks for your protection 'O Prophet', grant it to them so they may hear the Word of Allah, then escort them to a place of safety, for they are people who have no knowledge. (Qur'an, At-Tawbah 9:6) 
Besides, it reinforces that warfare is not for religious coercion, rather it is to ask non-Muslims to convert to Islam consciously and voluntarily.

If the purpose of the declaration of war against non-Muslims was religious coercion, Allah would have ordered the Messenger to detain those seeking protection and not release them from being prisoners of war until they convert to Islam forcibly or voluntarily. The exception in At-Tawbah stated that those who 'break their promises' need to be treated accordingly. al-Tawbah also mentioned in detail the factors causing the declaration of war against non-Muslims, and religious coercion is not included in these causes, as stated by al-Țabarī (2001). The concept of nasakh (abrogation) in the Qur'an, especially with regard to freedom of religion, has led to debates among mufassirs (interpreters) (Hasan 2016). These debates occurred because of the differences in understanding of nasakh, which contributed to the emergence of religious radicalism, leading to acts of terrorism. Ibn 'Āshūr explicitly stated that Al-Baqarah 2:256 abrogated the verses about war (āyāt al-Qitāl).

The contemporary Qur'anic interpreter, Rashīd Riḍa, rejected the concept of nasakh in the Qur'an. According to Riḍā, the Qur'an, Al-Baqarah 2:256, which contains the concept of religious freedom as well as general principles of Islam, is one of the fundamental aspects of Islamic law. It is also the teachings of the previous Prophets. Therefore, it applies to all times and cannot be confirmed by any verse. Verses with the principle of religious freedom were first revealed in Mecca, the period in which fundamental religious beliefs were formulated. Meanwhile, the verses that were revealed in Medina were generally in the position to strengthen the principal things that were revealed in Mecca (Ridâ 1999). Therefore, the Madaniyya verse does not have the ability to abrogate (annul) the Makkiyya verse because the character of the Makkiyya verses is eternal, humanist, egalitarian and universal (Mustaqim 2019).

\section{Debate between classical and contemporary Islamic Law experts regarding riddah}

The debate amongst Islamic legal experts regarding riddah arises because the Qur'an has never specifically explained the death penalty for riddah perpetrators, while there is a hadith that instructs such a penalty to be enforced, namely 'man baddala dīnahu faqtulūh' (Whoever changes their religion must be killed) (Al-Bukhari 1401). This contradiction between the verse and the hadith has led to the accusation that the teachings of Islam are contradictory. On one hand, it gives freedom to choose religion and on the other, it does not allow one to leave Islam.

This phenomenon also leads to the assumption that Islamic teachings seem to apply a dual system (ambiguous in nature) in deciding laws for those committing riddah. Various scholarly contributions have been made to determine a common ground between the two arguments that seem contradictory; however, the majority of classical Islamic legal experts' research studies are based solely on the approach of hadith methodology. When interpretation is done by considering the reasons for revelation, the comprehensive understanding and application of the hadith require historical, sociological and political approaches.

The study on the interpretation of the Qur'an regarding the issue of religious freedom and its relation to the death penalty for riddah perpetrators (murtad) has three schools of thought (mazhab). Firstly, most scholars and classical Islamic legal experts state that religious freedom in Islam has no effect to counter the death penalty for the perpetrator of the riddah. al-Mut' ini stated that the Prophet imposed the death penalty for riddah in three cases. Firstly, the Prophet ordered Muslims in Yemen to fight al-Aswad al-'Unsī who claimed to be a prophet and invited people to follow him. Therefore, based on the Prophet's order, the Muslims attacked and killed al-Aswad al-'Unsī. Secondly, the Prophet's order to kill four people at the Fathu Mecca incident. Two of them were Abdullah b. Khattāl and Abdullah b. Sa'ad b. Abī al-Sharh who converted to Islam before committing hostilities against the religion. Thirdly, Abu Bakr the first caliph and the ijma' (consensus) of the scholars regarding the death penalty for riddah perpetrators (Al-Mut'"îni 1994).

Secondly, the opinions of the majority of scholars and contemporary Islamic law experts confirm the need to reinterpret the hadith text, which imposes the death penalty for riddah perpetrators. The imposition of the death penalty contradicts the verse of the Qur'an, which in spirit violates religious freedom. Whenever the Prophet imposed the death penalty for riddah, it was to protect the Muslim community, as mentioned by the Qur'an, An-Nisā' 4:137 (An-Na'im 2001). The imposition of the death penalty for riddah was therefore not related to freedom of belief, rather, it was closely related to political matters such as treason against the nation, state and religion (An-Na'im 2007).

Contemporary Muslim thinker Jamāl al-Bannā (1998) criticised the sanad (chain of narrators) and matan (the content) of hadith man baddala dinnahu faqtulūh. In terms of the chain, there is a narrator named 'Ikrimah who narrated many hadiths from Ibn 'Abbās. However, Muslim b. al-Ḥajjāj refrained from accepting traditions narrated by 'Ikrima, except for one hadith regarding the problem of the hajj and the rank of maqrūn with Jubayr b. Sa'îd. According to al-Bannā (1998), Muslim b. al-Hajjāj deliberately rejected 'Ikrimah as he was known to have an understanding similar to that of the Khawārij (early outcast radical sect of Islam) and often received gifts from officials. In terms of the content, there is a version of the hadīth, which says that Ali b. Abī Tālib burned the riddah perpetrator as punishment. Al-Bannā (1998) thus begged the question of conflicting punishments, burning in this case. Al-Bannā (1998) also stated that the text of the hadith man baddala dinahu faqtulīh is general, therefore, it is interpreted as a conversion from Christianity to Judaism or otherwise. All these sanad and matan are issues that make the degree of the hadiths not applicable for legal rulings (Sa'id 1997). 
Some Muslim historians agree with this second opinion. Ibn 'Athīr emphasised that the imposition of the death penalty at the Fathu Mecca incident against Abdullah b. Sa'ad b. Abi al-Sharh was not because of apostasy, rather it was for spreading provocation to incite hostility against Islam. Meanwhile, Abdullah b. Khattāl was killed for committing a criminal act, namely the murder of a Muslim from the Anșār and a Roman who converted to Islam. This is similar to the death penalty against al-Aswad al-'Unsī for his claiming to be a prophet and hostility to Islam (Ibn al-Atsîr 1402).

In line with that, Ibn Kathīr emphasised that al-Aswad al-'Unsī claimed to be a Prophet and made a separatist movement that attacked the Messenger of Allah and Muslims. When serving as caliph, Umar b. Khațāa once inquired after the fate of six people from the Bakr b. al-Wā'il tribe who left Islam, and Anas stated that they have all been killed. Afterwards, Umar b. Khattāb was concerned about the incident and said Innā Lillāhi Wa Innā Ilaihi Rāji'ūn (From God, we come and unto him we return). When Umar b. Khațāab was asked why he was concerned, Umar b. Khattāa replied that he planned to invite the six people to convert to Islam again, but if they refused, they would be put in prison.

These incidents clearly indicate that the killings committed against the perpetrators of the riddah were not because of apostasy but rather for political reasons, namely conspiracy, provocation of hostility and acts of murder. Yūsuf al-Qardawi stated that the imposition of the death penalty for riddah perpetrators is a political decision by Prophet Muhammad, greatly influenced by the understanding of the political situation at that time. Some rulings change with the situation (Al-Qaradlâwî 1996). In line with that, a contemporary interpreter of the Qur'an from Indonesia, Muhammad Quraish Shihab stated that the hadith man baddala dinahu faqtulūh is contextual, and not universal, therefore, it cannot be a general benchmark applicable to all situations and conditions (Shihab 1998).

Some scholars and experts in Islamic law also distinguish the types of punishment imposed on riddah perpetrators. The death penalty for perpetrators of riddah is imposed assuming that their apostasy is committed alongside hostility towards Islam. It is not imposed assuming their apostasy is not followed by hostility (Ibn Taimiyah 1978). Some scholars and Islamic law experts also argue that riddah is a criminal act. The penalty for the perpetrator is not supposed to be death rather $t a^{\prime} z \bar{r}$ ( a sentence imposed by the state), which is a form of punishment in various forms. In Malaysia, it is associated with various punishments such as flogging, fines or a prison sentence of 3 years (Mohamed Adil 2005). For example, Nasr Hāmid Abū Zayd, a wellknown thinker from Egypt was accused of committing riddah by local authorities and convicted. However, the imposed sentence was not death (Berger 2003). In Indonesia, although riddah influences family laws such as child custody, local authorities do not impose the death penalty (Nurlaelawati 2016).

\section{Discussion}

\section{Maqāșidī interpretation and perspective on religious freedom and riddah}

Ibn 'Āshūr agreed with the majority of scholars regarding the prohibition of enforcing a religion on an individual. This is because it is against the principle of freedom that Allah has bestowed upon humans. Salāh al-aḩwāl al-fardiyya means the fulfilment of individual rights that are both physical and mental. One of the most important inner rights is the choice of belief or religion. Everyone is given the freedom by Allah to choose religion as the verse in the Qur'an, Al-Baqarah 2:256 and the Qur'an, Al-Kahf 18:29. Freedom of religion is one form of the manifestation of the sala hh al-aḩwāl al-fardiyya and saläh al-ahwwāl al-jamā'iyya, which is easily realised assuming that the salāh al-ahwāl al-fardiyya is fulfilled. Similarly, șalāh al-ahwwāl al-'ümrāniyya is created after the manifestation of șalāh al-ahwwāl al-jamá'iyya and șalāh al-ahwwāl al-fardiyya.

Therefore, in Ibn 'Āshūr's view, the religious aspect, which is personal in nature determines the civil aspect, which is communal and collective in nature. It subsequently becomes the determinant used to realise the goodness of human civilisation in the world. This is analysed from Ibn 'Āshūr's statement, which does not only limit the șalăh alahwōl al-fardiyya (individual goodness), with matters of worship that are physically visible in nature such as praying, fasting, zakat, etc. However, it also relates to inner worship, namely ethics towards others such as carrying out justice, equality of rights, including respecting religious freedom. Therefore, Ibn 'Āshūr viewed ethics as a derivative of the creed (belief) because of its importance in Islamic teachings.

In the context of this Maqāsidī interpretation, the death penalty for riddah needs to be reinterpreted in terms of several arguments. Firstly, the theological argument based on the hadith of the Prophet (PBBUH) indicates that those who committed riddah and separated themselves from the Muslim community were sentenced with the death penalty (al-Māriq min al-dīn al-Tārik li al-jamā'ah) as narrated by Abdullah b. Mas'ūd (Majah n.d.). This hadith indicates the existence of rebellious movements and separatism that interfere with the sovereignty of the country. Secondly, based on the historical argument, Abū Bakr fought against apostates, not simply because they changed religions or abandoned Islam. However, it was because they separated themselves from the Muslim congregation and refused to pay zakat.

Therefore, when people knowingly change religion without any support from any party, the death penalty cannot be imposed as it contradicts the dimensions of hifz al-nafs (guarding the soul). It also contradicts the dimensions of hifz al-din (safeguarding religion) which includes the freedom to choose a religion. It is mandatory to maintain religious freedom in a country that adheres to the nation-state system. 
This is one of the principles in Maqāșidī Interpretation, where the mufassirs (interpreters) do not only look at the text of the verse, rather they also need to visualise the context and reality. The principles of global ethics in interactions among human beings also need to be considered.

When religious freedom in the perspective of the Maqāșidi Interpretation is applied to riddah, contextualising it from the historical application of punishment alone becomes redundant. When the death penalty is imposed on riddah perpetrators, it becomes contrary to the social reality of contemporary life, which emphasises on the values of social justice, equality, peace and ease of life, which are the core and purpose of religious life. The shift in meaning in Islamic law is a necessity because of social change which causes changes in religious thought patterns and views (religious worldview). Furthermore, this shift in meaning arises because of the importance of human dignity, inter-religious relations and the emergence of the concept of a nation-state (non-Islamic state) which has an impact on equality and equal treatment of all citizens. This social change in Jasser Auda's view had an impact on the construction of Islamic law in the form of a paradigm shift from classical maqāșid theory to contemporary maqāșid. The classical maqāsid paradigm emphasises the meaning of protection and preservation, while the contemporary maqāsid is associated with development and rights (Auda 2008).

Jasser Auda elaborated on the maqāṣid sharī'a formulated by Ibn 'Āshūr using a systems approach in Islamic legal philosophy. When maqāșid sharī'a reasoning is associated with hifz al-din and religious freedom, it becomes a derivative or part of the concept in the classical maqāșid paradigm which means protection and preservation. According to Auda, the meaning of hifz al-dīn in the classical maqāșid paradigm needs to be developed into contemporary hifz al-din which emphasises on the protection of religious freedom and human rights. According to the classical maqasid paradigm, religious freedom has no effect on the imposition of the death penalty for riddah perpetrators because it is an act that prevents the realisation of hifz al-dinn (religious preservation).

Meanwhile, according to the contemporary maqasid paradigm, the classical perspective of hifz al-din needs to be developed into the contemporary hifz al-din concept, because riddah is a classical concept with social and political nuances different from today's society. Therefore, the development of the classical perspective of the hifz al-din concept, which emphasises the death penalty for riddah perpetrators is the protection of religious freedom and conversion in the perspective of contemporary hifz al-dìn. When using the Maqāșidī Interpretation of Ibn 'Āshūr, it becomes impermissible to apply the death penalty for riddah perpetrators. Moreover, it contradicts the dimension of hifz al-nafs (guarding the soul) and is also against the dimension of hifz al-din (maintaining religion), which includes and maintains the freedom to choose a religion, especially in a country like Indonesia which applies a nation-state system.

\section{Conclusion}

This study shows that the Maqasidi Interpretation of Ibn 'Āshūr's provides space for the need to re-evaluate and interpret the death penalty for riddah perpetrators because it is in addition to contradicting the dimensions of maintaining religion (Hifz al-Dinn) and preserving the soul (Hifz al-Nafs), which as the principle of Maqāșid Sharia also contradicts the theological, historical and political reality. Based on the theoretically conceptual thinking, Maqāșidî Interpretation of Ibn 'Āshūr's adopts the concept of classical Islamic jurist such as al-Ghazālì and al-Shațibì who classify Maqāṣid sharīa into five principles, namely the maintenance of religion, soul, mind, descendants and property. However, in more applicative way, Ibn 'Āshūr develops its operational scope into contemporary and contextual issues that are relevant pivots on three things, namely șalāh al-ahwwāl al-fardiyyah (individual goodness), șalāh al-ahwōal al-jamā'iyyah (collective good) and șalāh alahwōl al-'umrāniyyah (goodness of civilisation). The development of the scope of Maqāsid Sharīa that Ibn 'Āshūr has worked on is close to the thoughts of current Maqāșidī (Islamic legal theory) experts such as 'Allāl al-Fāsī and Yūsuf al-Qarḍāwī. It can be seen from several current issues that affect the current Maqāșid Sharīa study map, such as the enforcement of human rights including the right to life, the right to honour, the right to freedom both physical (body) and non-physical, such as freedom of religion and belief.

\section{Acknowledgements}

The authors would like to thank numerous individuals for their contributions to the input, editing and formatting of this work.

\section{Competing interests}

The authors declare that they have no financial or personal relationships that may have inappropriately influenced them in writing this article.

\section{Authors' contributions}

The contribution of L.S.B.M. in this article was to collect resources and write systematically on Ibn 'Āshūr's thoughts relating to religious freedom and riddah. Additionally, he also carefully analysed the content of the article and then made conclusions. K.H. contributed to the theoretical framework and research methods used, and helped with translation.

\section{Ethical considerations}

The Head of Research Institute Mataram State Islamic University would like to declare that the research entitled 'Religious freedom and riddah through the maqāșidī interpretation of Ibn 'Āshūr' by Dr Lalu Supriadi Bin Mujib and Dr Khairul Hamim is a theoretical or conceptual study and no human or animal participants involved. Therefore, 
this study has no risk in the future - 217/Un.12/LP2M/ PP.00.9/06/2021.

\section{Funding information}

This research received no specific grant from any funding agency in the public, commercial, or not-for-profit sectors.

\section{Data availability}

The authors declare that they have no financial or personal relationships that may have inappropriately influenced them in writing this article.

\section{Disclaimer}

The views and opinions expressed in this article are those of the authors and do not necessarily reflect the official policy or position of any affiliated agency of the authors.

\section{References}

Abu Hamid al-Gazali, n.d., Al-Mustashfa Min 'Ilm Al-Ushul, 1st edn., Dar Ihya' al-Turats al-Arabi, Beirut.

Akbar, A., 2018, 'The classical Islamic laws of apostasy in the present context', International Journal of Humanities and Social Science 12(6), 697-702.

Akbar, A. \& Saeed, A., 2020, 'Death penalty for apostasy: Selected Sunni and Shi'a scholars' views in favour of abolition', Melbourne Asia Review 4, 1-8. https://doi. org/10.37839/MAR2652-550X4.17

Al-'Alwânî, T.J., 2014, Al-Jam'u Bayna al-Qirâ'atayn: Al-Wahy wa al-Kaun, Dar al-Salam, Kairo.

Al-Bannā, J., 1998, Kallâ Thumma Kallâ, Kallâ li Fuqahâ' al-Taqlîd wa Kallâ li Ad'iyấ' al-Tanwîr: Muhakamah al-Fikr al-Misrî, Dar al-Fikr al-Islami, Kairo.

Al-Bukhari, M.B.I., 1401, Shahih Al-Bukhari, 50p., Dar al-Fikr, Beirut.

al-Fāsī 'Allāl, 1995, Maqāșid al-Syari'ah al-Is/āmiyyah wa Makārimuhā, 5th edn., Dār al-Garb al-Islāmi, Beirut.

Al-Mut"îni, A. al-AIM, 1994, Uqûbat al-Irtidâd 'an al-Dîn Bayn al-Adillah al-Sharî'ah wa Shubhât al-Munkirîn, pp. 62-64, Maktabah Wahbah, Kairo.

Al-Qaradlâwî, Y., 1996, Jarîmah al-Riddah wa 'Uqûbat al-Murtad fí Dlaw' al-Qurân wa al-Sunnah, 41p., Mu'assasah al-Risalah, Beirut.

Al-Qurtubî, A'Abd A.M.B.A.B.A.B., 2002, al-Jâmi' li Ahkâm al-Qur'ân, Dar al-Hadits, Kairo.

Al-Shāțib̄i, A.I., n.d., al-Muwāfaqāt fi Ușul al-Sharī'ah, A. Darrāz (ed.), Dar al-Fikr al-'Ārabi, Kairo.

al-Ṭabarī, I.J., 2001, Jāmi' al-Bayān 'an Ta'wīl Āyi al-Qur'ān, 1st edn., Dar al-Fikr, Beirut. Al-Zamakhsharī, A. al-Q., 1407, al-Kasshāf 'an Haqā'iq Gawāmid al-Tanzīl, 3rd edn., Dar al-Kitab al-Arabi, Beirut.

An-Na'im, A.A., 2001, Toward an Islamic reformation: Civil Liberties, Human Rights and International Law [Dekonstruksi Syariah: Wacana Kebebasan Sipil, Hak Asasi Manusia dan Hubungan Internasional dalam Islam], 178p., transl. A. Suaedy \& A. Ar-Rany, LKiS, Yogyakarta.

An-Na'im, AA., 2007, Islam and the secular state: Negotiating the future of Shari'a [Islam dan Negara Sekular: Menegosiasikan Masa Depan Syariah], 187p., transl. S. Murniati, PT. Mizan Pustaka, Bandung.

Arkoun, M., 1988, The politics of Islamic revivalism, S.T. Hunter (ed.), Bloomington, Indiana University Press, IN.

Assagaf, J., 2014, 'Kontekstualisasi hukum murtad dalam perspektif sejarah sosial hadis [Contextualization of Apostate Law in the socio-historical perspective of Hadith]', ljtihad: Jurnal Wacana Hukum Islam dan Kemanusian 14(1), 21. https:// doi.org/10.18326/ijtihad.v14i1.21-39

Auda, J., 2008, Maqashid Syariah as philosopy of Islamic law system approach, International linstitute of Islamic Tought, Herndon, VA.

Baker, M., 2018, 'Capital punishment for apostasy in Islam', Arab Law Quarterly 32(4), 439-461. https://doi.org/10.1163/15730255-12324033

Berger, M.S., 2003, 'Apostasy and public policy in contemporary Egypt: An evaluation of recent cases from Egypt's highest courts', Human Rights Quarterly 25(3), 720-740. https://doi.org/10.1353/hrq.2003.0026

Fawaid, A., 2017, 'Maqasid al-Qur'an dalam Ayat Kebebasan Beragama Menurut Penafsiran Thaha Jabir al-'Alwani [Maqasid Al-Qur'an In Verse of Religious Freedom According to Thaha Jabir Al-'Alwani Interpretation]', Madania 21(2), 113-126. https://doi.org/10.29300/madania.v21i2.571

Fikriyati, U., 2015, 'Maqâsid al-Qur'ân dan Deradikalisasi Penafsiran dalam Konteks Keindonesiaan [Maqâsid Al-Qur'ân and Deradicalization of Interpretation in Indonesian Context]', ISLAMICA: Jurnal Studi Kesilaman 9(1), 244. https://doi. org/10.15642/islamica.2014.9.1.244-267
Fikriyati, U., 2019, 'Maqāsid Al-Qur'ān: Genealogi Dan Peta Perkembangannya Dalam Khazanah Keislaman [Maqāsid Al-Qur'ān: Genealogy and map of its development in islamic treasure]', Anil Islam: Jurnal Kebudayaan dan IImu Keislaman 12(2), in islamic tris.

Hasan, M. \& Kholiq, A., 2018, 'Interfaith tolerance and its relevance to the indonesian diversity: A study on Ibn Ashur's al-Tahrir wa al-Tanwir', ULUMUNA: Journal of Islamic Studies 22(2), 333-362. https://doi.org/10.20414/ujis.v22i2.301

Hasan, M.A.K., 2016, 'Ayat-Ayat Kebebasan Beragama Dalam Perspektif Nasakh: Kajian Terhadap Penafsiran Ibn Kathîr Dan Rashîd Ridâ [Verses of religious freedom in the perspective of the Nasakh: Study of the interpretation of Ibn Kathîr and Rashîd Ridâ]', Mutawatir: Jurnal Keilmuan Tafsir Hadis 6(2), 284-313. https:// doi.org/10.15642/mutawatir.2016.6.2.284-313

Herlambang, S. \& Juliandi, B., 2018, 'Ibn 'Ashur And negation of minority's contribution to development of nation', ULUMUNA: Jurnal of Islamic Studies 22(1), 34-56. https://doi.org/10.20414/ujis.v22i1.306

Ibn al-Atsîr, M., 1402, Al-Kâmil Fî Al-Târîkh, Dar al-Shadir, Beirut.

Ibn 'Āshūr, M. al-T., n.d., al-Taḥrīr wa al-Tanwīr, Dar Sahnun li al-Nashr wa al-Tawzi, Tunis.

Ibn 'Āshūr, M. al-T., 2011, Maqāșid al-Sharī'ah al-Islāmiyyah, H. Bosemah (ed.), Dār al-Kitāb al-Lubnāni \& Dār al-Kitāb al-Mishri, Beirut.

Ibn Kathir, I.K., 1966, Al-Bidāyah Wa Al-Nihāyah, 1st edn., al-Ma'arif, Beirut.

Ibn Taimiyah, A. al-H., 1978, Al-Sârim al-Maslûl 'alâ Shâtim al-Rasûl, 321p., Dar alKutub al-Ilmiyah, Beirut.

Ibrahim, Y.S., 2014, 'An examination of the modern discourse on Maqāșid al-Sharī'a', The Journal of the Middle East and Africa 5(1), 39-60. https://doi.org/10.1080/21 520844.2014.882676

Islam, T., 2011, 'Maqasid Al-Qur'an: A search for a scholarly definition', Al-Bayan Journal of Qur'an and Hadith Studies 9(1), 189-207. https://doi. org/10.1163/22321969-90000026

Islam, T., 2013a, 'Maqasid Al-Qur'an and Maqasid Al-Shari'ah: An analytical presentation', Revelation and Science 3(01), 50-60.

Islam, T., 2013b, 'The Genesis and development of The Maqasid al-Qur'an', American Journal of Islamic Social Sciences 30(3), 39-58. https://doi.org/10.35632/ajiss. v30i3.301

Kathîr, I., 1999, Tafsîr al-Qur'ân al-Azîm, Dar al-Fikr, Beirut.

Koentjaraningrat, K., 1990, Metode-Metode Penelitian Masyarakat [Community research methods], Gramedia Pustaka Utama, Jakarta.

Kusmana, K., 2015, ‘Paradigma al-Qur'an: Model Analisis Tafsir Maqasidi dalam Pemikiran Kuntowijoyo [Al-Qur'an paradigm: Analysis model of Maqasidi interpretation in Kuntowijoyo's thought]', Afkaruna 11(2), 220-239. https://doi. org/10.18196/aiijis.2015.0049.220-239

Majah, I., n.d., Sunan Ibn Majah, No 2534, Kitab al-Hudud, 846p., Dar al-Kutub al-Ilmiyah, Beirut.

March, A.F., 2011, 'Islamic legal theory, secularism and religious pluralism: Is modern religious freedom sufficient for the Shari'a "Purpose [Maqsid]" of "Preserving Religion [Hifz Al-Din]"?', Islamic Law and Law of The Muslim World, Paper no Religion [Hifz Al-Din]"?', Islamic Law and Law of The
09-78; Yale Law Public School, Working Paper No. 208.

Mohamed Adil, M.A., 2005, 'Punishment for apostasy: Conflict between the right to freedom of religion and criminal sentence, a case study in Malaysia', Jurnal CITU, viewed n.d., from http://ir.uitm.edu.my/11531/1/AJ MOHAMED AZAM viewed n.d., from http://ir
MOHAMED ADIL CITU 05.pdf.

Mohamed Adil, M.A., 2007, 'Law of apostasy and freedom of religion in Malaysia', Asian Journal of Comparative Law 2(1), 1-36. https://doi.org/10.2202/19320205.1060

Musif, A., 2015, 'Pemikiran Islam Kontemporer Abdullah Saeed dan Implementasinya dalam Persoalan Riddah [Abdullah Saeed's contemporary islamic thought and its implementation in the Riddah case]', Ulumuna 19(1), 79-92. https://doi. org/10.20414/ujis.v19i1.1251

Mustaqim, A., 2019, Argumentasi Keniscayaan Tafsir Maqasidi Sebagai Basis Moderasi Islam [Argumentation of the necessity of Maqasidi's interpretation as the basis of Islamic moderation], Universitas Negeri Islam, Yogyakarta.

Nikmah, L., 2017, Penafsiran Tahir ibn 'Asyur terhadap ayat-ayat tentang demokrasi: Kajian atas tafsir al-Tahrir wa al-Tanwir [The interpretation of Tahir Ibn 'Asyur on democracy verses: A study of the Tafsir Al-Tahrir Wa Al-Tanwir], Universitas Islam Negeri Walisongo. https://doi.org/10.21580/JISH.21.2517

Noorhidayati, S., 2016, 'Hubungan Antar Umat Beragama Dalam Perspektif Hadis [Relations between religious communities in the perspective of the Hadith]', Kalam 10(2), 491-516. https://doi.org/10.24042/klm.v10i2.11

Nurlaelawati, E., 2016, 'For the sake of protecting religion: Apostasy and its judicial impact on Muslim's marital life in Indonesia', Journal of Indonesian Islam 10(01), 89-112. https://doi.org/10.15642/JIIS.2016.10.1.89-112

Nuruddin, A., Qarib, A., Lubis, A. \& Hamdani, M.F., 2019, 'Relationship of interfaith in Tunisia (Critical Study of Ibn 'Ashur Tafsir' W.1973)', Budapest International Research and Critics Institute (BIRCI-Journal): Humanities and Social Sciences 2(1), Research and Critics Institute (BIRCI-Journal): Humanit
353-372. https://doi.org/10.33258/birci.v2i1.208

Ridâ, M.R., 1999, Tafsîr al-Qur'ân al-Hakîm, Dâr al-Kutub al-Ilmîyah, Beirut.

Sa'id, J., 1997, Lâ Ikrâha fi al-Dîn: Dirâsât wa Abhâth fí al-Fikr al-Islâmî, al-'Ilm wa alSalâm li al-Dirâsah wa al-Nashr, Damaskus.

Saed, A., 2006, Laporan Seminar dengan tema Civil and Political Rights (Fundamental Liberties), p. 74, MIEHRI, Hotel Hilton Malaysia tanggal, 16 Mei 2006.

Saeed, A. \& Saeed, H., 2004, Freedom of religion, apostasy and Islam, Ashgate Publishing Limited, Aldershot. 
Shihab, M.Q., 1998, 'Wawasan Al-Qur"an tentang Kebebasan Beragama"', in K. Hidayat \& A. Gaus (eds.), Passing over: Melintasi Batas Agama [The Qur'anic Insights on Religious Freedom], in K. Hidayat \& A. Gaus (eds.), Passing over: Crossing religious, p. 180, Gramedia-Paramadina, Jakarta.
Sumbulah, U. \& Purnomo, A., 2017, 'Muslim debates on Riddah and freedom of religion', The Social Sciences 12(12), 2299-2307.

Umayah, 2016, 'Tafsir Maqashidi: Metode Alternatif Dalam Penafsiran Al-Qur'an', Diya Al-Afkar 4(1), 36-58. 